\title{
Secreted Protein Acidic and Rich in Cysteine as a Molecular Physiological and Pathological Biomarker
}

\author{
Abdelaziz Ghanemi ${ }^{1,2}$ (D), Mayumi Yoshioka ${ }^{1}$ (D) and Jonny St-Amand ${ }^{1,2, *(D)}$ \\ 1 Functional Genomics Laboratory, Endocrinology and Nephrology Axis, CHU de Québec-Université Laval \\ Research Center, Québec, QC G1V 4G2, Canada; Abdelaziz.Ghanemi@crchudequebec.ulaval.ca (A.G.); \\ mayumi.yoshioka@crchudequebec.ulaval.ca (M.Y.) \\ 2 Department of Molecular Medicine, Faculty of Medicine, Laval University, Québec, QC G1V 0A6, Canada \\ * Correspondence: jonny.st-amand@crchudequebec.ulaval.ca; Tel.: +1-(418)-654-2296; Fax: +1-(418)-654-2761
}

check for updates

Citation: Ghanemi, A.; Yoshioka, M.; St-Amand, J. Secreted Protein Acidic and Rich in Cysteine as a Molecular Physiological and Pathological Biomarker. Biomolecules 2021, 11, 1689. https://doi.org/10.3390/

biom 11111689

Academic Editor: Yunkai Zhang

Received: 1 November 2021

Accepted: 12 November 2021

Published: 13 November 2021

Publisher's Note: MDPI stays neutral with regard to jurisdictional claims in published maps and institutional affiliations.

Copyright: (c) 2021 by the authors. Licensee MDPI, Basel, Switzerland. This article is an open access article distributed under the terms and conditions of the Creative Commons Attribution (CC BY) license (https:// creativecommons.org/licenses/by/ $4.0 /)$.

\begin{abstract}
Secreted protein acidic and rich in cysteine (SPARC) is expressed in diverse tissues and plays roles in various biological functions and processes. Increased serum levels of SPARC or its gene overexpression have been reported following numerous physiological and pathological changes including injuries, exercise, regeneration, obesity, cancer, and inflammation. Such expression pattern interrelation between these biological changes and the SPARC expression/secretion points to it as a biomarker. This property could lead to a variety of potential applications ranging from mechanistic studies and animal model validation to the clinical and therapeutic evaluation of both disease prognosis and pharmacological agents.
\end{abstract}

Keywords: secreted protein acidic and rich in cysteine; expression; physiology; pathology; biomarker

Secreted protein acidic and rich in cysteine (SPARC), also called BM- 40 and osteonectine, is a non-collagenous [1] and collagen-binding [2], plays a non-structural role in ECM/bone [3], and has three structural domains with active glycoproteins [4] that was initially reported in bones under another name, osteonectine [1]. Additionally, studies have highlighted its implications in numerous physiological and pathological contexts at different biological levels, including in injuries and wound healing [5-8], exercise and exercise-induced muscle changes [9-11], glucose homeostasis and insulin secretion [12,13], metabolism and energy balance [14,15], regeneration [16], inflammation [17-19], cancer [20-25], obesity and diabetes [26], fibrillar collagen assembly and extracellular matrix maintenance and remodelling [17,27,28], lipid metabolism [29], immunity [30], myocardial repair and fibrosis [2], and vascular biology [31].

Importantly, SPARC protein and gene expression or its serum level changes are involved in an increase during a variety of situations. For injuries in the adult rat cerebral cortex, cortical brain injury leads to an increased expression of Sparc mRNA in the blood vessels [32]. While serum SPARC increases with obesity [33], its levels are reduced following bariatric surgery for weight loss [34]. In addition, the fat mass also correlates with the human adipose tissue SPARC expression [35], and SPARC mRNA expression in the adipose tissue is correlated to body mass index [33], which points to SPARC as a molecular indicator of the adiposity percentage. In oncology, many studies have shown that SPARC is overexpressed in different forms of cancer, including cervical carcinoma [36], colon cancer [37], and hepatocellular carcinoma [38]. Moreover, in patients with cervical carcinoma [36] or ampullary cancer [39], such overexpression is associated with a poor prognosis, and increased serum SPARC levels have been reported in melanoma patients as well [40]. Interestingly, the serum SPARC level has been proposed as a pancreatic cancer marker, as it has also been correlated to tumour size [41]. Serum SPARC levels also correlate with coronary artery lesion severity in type 2 diabetic patients with coronary heart disease [42], and newly diagnosed type 2 diabetes mellitus patients also have high plasma 
SPARC levels [43]. In addition to these illustrative examples, SPARC/Sparc overexpression has also been reported in inflammation [44], following exercise [45], and during skeletal muscle regeneration [46]. All of these elements highlight the molecular importance that SPARC has biologically. Regarding the expression pattern and how SPARC is circulated, we have hypothesized that its secretion would be involved in controlling or reducing the biological damage that is associated with the processes that initially lead to its increase (feedback-like mechanism). This is, for instance, illustrated by the increase of SPARC during both obesity and cancer as well as the SPARC properties to inhibit both adipogenesis and tumor development $[14,21]$. Furthermore, SPARC has been found both extracellularly and intracellularly [47] in addition to its presence in the blood, a distribution and secretion pattern that support classifying it as a biomarker.

The objective of this piece of writing is to introduce the concept of measuring SPARC protein or gene expression/level in selected biological samples as a biomarker that has potential applications in the diverse fields of biomedical research as well as in clinical practice. Indeed, since SPARC/Sparc expression/secretion changes with various diseases and physiological status, measuring the expression levels of SPARC (or its genes, SPARC/Sparc) or SPARC serum levels could allow the determination of how severely the disease has advanced, how efficient the treatment is, or how the pathogenesis evolves. The biological significance of such status-dependent expression patterns would lead to numerous potential biomedical and clinical applications (Figure 1). For instance, whereas high SPARC levels would reflect a disease evolution or a poor prognosis, decreased SPARC levels would be considered as an indicator of positive disease evolution or a reduced severity. The same logic applies to therapeutic evaluation in which reduced SPARC expression/level could indicate treatment efficacy. It seems acceptable to assume that the precision of such an evaluation would be higher in the tissues that express the most SPARC compared to those that express it less. Furthermore, changes during pathological phases could allow SPARC expression to be followed throughout different disease stages as a marker and thus to build a reference library for diagnosis and prognosis evaluation based on SPARC levels. Similarly, it can also be used to evaluate disease treatments since it may change with diseases improvement. Therefore, we suggest the use of SPARC as a biomolecular evaluation tool either during disease progress, treatment, or during studies aiming to evaluate disease pathogenesis. Pathogenesis exploration, mechanism studies, and animal model validations represent other applications that can be achieved through the expression of SPARC within pathway models and as a validation criterion for animal model building.

Importantly, with this expression specificity of SPARC within different pathological contexts, the potential implications of SPARC in pathogenesis are worthy of further exploration in order to identify new therapeutic targets, drugs, or adjuvants for metabolic disorders, inflammation, or cancer, especially because SPARC has been shown to play roles related to the cytotoxic effect of sorafenib against hepatocellular carcinoma cells [48]. To conclude, the interindividual differences in terms of SPARC expression in pathophysiological and therapeutic contexts can contribute to the optimization of a precision medicine supported by advanced methods in screening and sequencing. These perspectives are relevant to various applications ranging from biomolecular medical research to clinical applications. There are some challenges that have yet to be overcome. The first challenge would be the detection method and whether to use the protein level or the mRNA level as a marker. This would mainly depend on the available biological samples (sampling would depend on the patient's physiopathological status) as well as the laboratory equipment/budget. If more than one type of sample is available, then the choice requires further studies in order to first evaluate whether the protein level and mRNA level are equivalently accurate to build standard measurement methods. Overall, we still need more in-depth studies and comparative measures to determine SPARC/Sparc measuring protocols for each physiological or pathological condition in order to determine the more convenient methods for use in a hospital laboratory. 


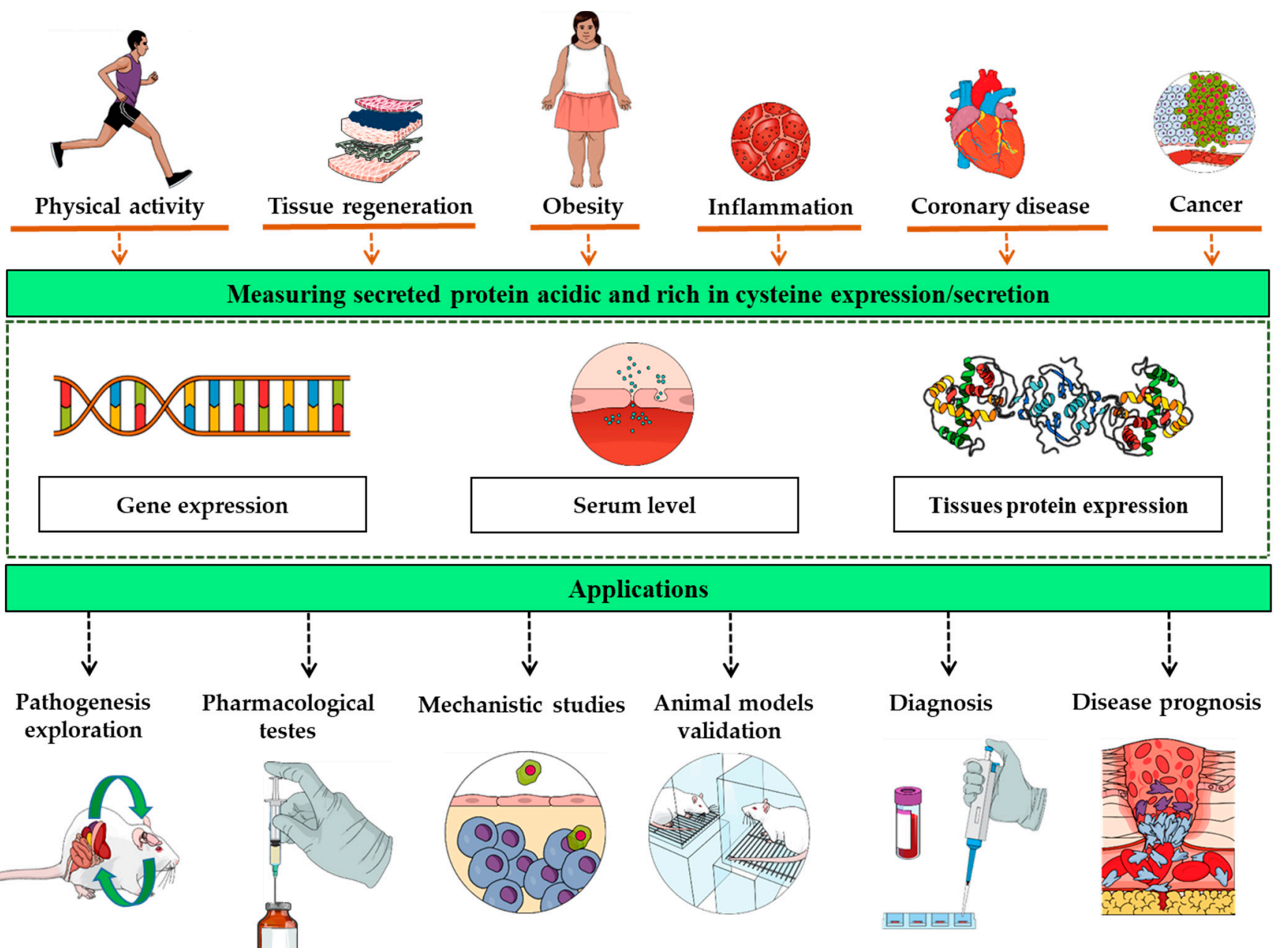

Figure 1. The overexpression of the secreted protein acidic and rich in cysteine gene, protein, or its increased blood concentration follow numerous physiological and pathological changes including exercise, obesity, cancer, injuries, and inflammation. Such interrelation between these biological changes and the secreted protein acidic and rich in cysteine expression/secretion points to it as a biomarker with a variety of potential applications, ranging from mechanistic studies to the clinical and therapeutic evaluation of both disease prognosis and pharmacological agents.

Herein, SPARC/Sparc illustrates how identifying biomolecules and elucidating their related expression patterns based on pathophysiological variables could lead to the identification novel, yet specific, biomarkers that could be used as parameters for diagnosis, prognosis, therapeutic tests, and clinical evaluation.

Author Contributions: A.G. designed the manuscript structure and wrote it. A.G., M.Y., and J.S.-A. discussed the content and exchanged ideas and suggestions (concepts to add, Figure 1, references selection, etc.) throughout the writing process, edited, and critically revised the paper. J.S.-A. gave the final approval for the version to be published. All authors have read and agreed to the published version of the manuscript.

Funding: This work received no external funding.

Institutional Review Board Statement: Not applicable.

Informed Consent Statement: Not applicable.

Data Availability Statement: Not applicable. 
Acknowledgments: Abdelaziz Ghanemi received a scholarship under the Merit Scholarship Program for foreign students from the Ministry of Education and Higher Education of Quebec, Canada. The Fonds de recherche du Québec-Nature et technologies (FRQNT) is responsible for managing the program (Bourses d'excellence pour étudiants étrangers du Ministère de l'Éducation et de l’Enseignement supérieur du Québec, Le Fonds de recherche du Québec-Nature et technologies (FRQNT) est responsable de la gestion du programme). Abdelaziz Ghanemi received the scholarship « Bourse Tremplin-Stage en milieu de pratique» (Internship scholarship) from the Fonds de recherche du Québec-Sante (FRQS), Quebec, Canada. Figure 1 was created using images from https:// mindthegraph.com/ (Accessed on 12 September 2021).

Conflicts of Interest: The authors declare that there are no conflict of interest.

\section{References}

1. Rosset, E.M.; Bradshaw, A.D. SPARC/osteonectin in mineralized tissue. Matrix Biol. 2016, 52-54, 78-87. [CrossRef]

2. Bradshaw, A.D. The role of secreted protein acidic and rich in cysteine (SPARC) in cardiac repair and fibrosis: Does expression of SPARC by macrophages influence outcomes? J. Mol. Cell. Cardiol. 2016, 93, 156-161. [CrossRef] [PubMed]

3. Chlenski, A.; Guerrero, L.J.; Salwen, H.R.; Yang, Q.; Tian, Y.; Morales La Madrid, A.; Mirzoeva, S.; Bouyer, P.G.; Xu, D.; Walker, M.; et al. Secreted protein acidic and rich in cysteine is a matrix scavenger chaperone. PLoS ONE 2011, 6, e23880. [CrossRef] [PubMed]

4. Motamed, K. SPARC (osteonectin/BM-40). Int. J. Biochem. Cell. Biol. 1999, 31, 1363-1366. [CrossRef]

5. Wang, L.Y.; Zhang, Y.T.; Du, L.Q.; Wu, X.Y.; Zhu, J. The Effect of SPARC on the Proliferation and Migration of Limbal Epithelial Stem Cells During the Corneal Epithelial Wound Healing. Stem Cells Dev. 2021, 30, 301-308. [CrossRef]

6. Basu, A.; Kligman, L.H.; Samulewicz, S.J.; Howe, C.C. Impaired wound healing in mice deficient in a matricellular protein SPARC (osteonectin, BM-40). BMC Cell Biol. 2001, 2, 15. [CrossRef]

7. Mazzolini, G.; Atorrasagasti, C.; Onorato, A.; Peixoto, E.; Schlattjan, M.; Sowa, J.P.; Sydor, S.; Gerken, G.; Canbay, A. SPARC expression is associated with hepatic injury in rodents and humans with non-alcoholic fatty liver disease. Sci. Rep. 2018, 8, 725. [CrossRef]

8. Chen, S.; Zou, Q.; Chen, Y.; Kuang, X.; Wu, W.; Guo, M.; Cai, Y.; Li, Q. Regulation of SPARC family proteins in disorders of the central nervous system. Brain Res. Bull. 2020, 163, 178-189. [CrossRef]

9. Melouane, A.; Ghanemi, A.; Aubé, S.; Yoshioka, M.; St-Amand, J. Differential gene expression analysis in ageing muscle and drug discovery perspectives. Ageing Res. Rev. 2018, 41, 53-63. [CrossRef]

10. Ghanemi, A.; Melouane, A.; Yoshioka, M.; St-Amand, J. Exercise and High-Fat Diet in Obesity: Functional Genomics Perspectives of Two Energy Homeostasis Pillars. Genes 2020, 11, 875. [CrossRef]

11. Ghanemi, A.; Melouane, A.; Yoshioka, M.; St-Amand, J. Exercise Training of Secreted Protein Acidic and Rich in Cysteine (Sparc) KO Mice Suggests That Exercise-Induced Muscle Phenotype Changes Are SPARC-Dependent. Appl. Sci. 2020, 10, 9108. [CrossRef]

12. Atorrasagasti, C.; Onorato, A.; Gimeno, M.L.; Andreone, L.; Garcia, M.; Malvicini, M.; Fiore, E.; Bayo, J.; Perone, M.J.; Mazzolini, G.D. SPARC is required for the maintenance of glucose homeostasis and insulin secretion in mice. Clin. Sci. (Lond.) 2019, 133, 351-365. [CrossRef]

13. Hu, L.; He, F.; Huang, M.; Zhao, Q.; Cheng, L.; Said, N.; Zhou, Z.; Liu, F.; Dai, Y.S. SPARC promotes insulin secretion through down-regulation of RGS4 protein in pancreatic $\beta$ cells. Sci. Rep. 2020, 10, 17581. [CrossRef]

14. Ghanemi, A.; Yoshioka, M.; St-Amand, J. Secreted Protein Acidic and Rich in Cysteine: Metabolic and Homeostatic Properties beyond the Extracellular Matrix Structure. Appl. Sci. 2020, 10, 2388. [CrossRef]

15. Ghanemi, A.; Melouane, A.; Yoshioka, M.; St-Amand, J. Secreted protein acidic and rich in cysteine and bioenergetics: Extracellular matrix, adipocytes remodeling and skeletal muscle metabolism. Int. J. Biochem. Cell Biol. 2019, 117, 105627. [CrossRef]

16. Ghanemi, A.; Yoshioka, M.; St-Amand, J. Secreted Protein Acidic and Rich in Cysteine as A Regeneration Factor: Beyond the Tissue Repair. Life 2021, 11, 38. [CrossRef] [PubMed]

17. Riley, H.J.; Bradshaw, A.D. The Influence of the Extracellular Matrix in Inflammation: Findings from the SPARC-Null Mouse. Anat. Rec. (Hoboken) 2020, 303, 1624-1629. [CrossRef] [PubMed]

18. Ghanemi, A.; Yoshioka, M.; St-Amand, J. Secreted protein acidic and rich in cysteine and inflammation: Another homeostatic property? Cytokine 2020, 133, 155179. [CrossRef] [PubMed]

19. Tanaka, M.; Takagi, T.; Naito, Y.; Uchiyama, K.; Hotta, Y.; Toyokawa, Y.; Ushiroda, C.; Hirai, Y.; Aoi, W.; Higashimura, Y.; et al. Secreted protein acidic and rich in cysteine functions in colitis via IL17A regulation in mucosal CD4(+) T cells. J. Gastroenterol. Hepatol. 2018, 33, 671-680. [CrossRef]

20. Framson, P.E.; Sage, E.H. SPARC and tumor growth: Where the seed meets the soil? J. Cell Biochem. 2004, 92, 679-690. [CrossRef] [PubMed]

21. Ghanemi, A.; Yoshioka, M.; St-Amand, J. Secreted protein acidic and rich in cysteine and cancer: A homeostatic hormone? Cytokine 2020, 127, 154996. [CrossRef]

22. Wong, S.L.; Sukkar, M.B. The SPARC protein: An overview of its role in lung cancer and pulmonary fibrosis and its potential role in chronic airways disease. Br. J. Pharmacol. 2017, 174, 3-14. [CrossRef] 
23. Bao, J.M.; Dang, Q.; Lin, C.J.; Lo, U.G.; Feldkoren, B.; Dang, A.; Hernandez, E.; Li, F.; Panwar, V.; Lee, C.F.; et al. SPARC is a key mediator of TGF- $\beta$-induced renal cancer metastasis. J. Cell. Physiol. 2021, 236, 1926-1938. [CrossRef] [PubMed]

24. Camacho, D.; Jesus, J.P.; Palma, A.M.; Martins, S.A.; Afonso, A.; Peixoto, M.L.; Pelham, C.J.; Moreno, E.; Gogna, R. SPARC-p53: The double agents of cancer. Adv. Cancer Res. 2020, 148, 171-199. [PubMed]

25. Feng, J.; Tang, L. SPARC in Tumor Pathophysiology and as a Potential Therapeutic Target. Curr. Pharm. Des. 2014, 20, 6182-6190. [CrossRef] [PubMed]

26. Kos, K.; Wilding, J.P. SPARC: A key player in the pathologies associated with obesity and diabetes. Nat. Rev. Endocrinol. 2010, 6, 225-235. [CrossRef]

27. Whittal, M.C.; Molladavoodi, S.; Zwambag, D.P.; Millecamps, M.; Stone, L.S.; Gregory, D.E. Mechanical Consequence of Induced Intervertebral Disc Degeneration in the SPARC-Null Mouse. J. Biomech. Eng. 2021, 143, 024501. [CrossRef]

28. McCurdy, S.; Baicu, C.F.; Heymans, S.; Bradshaw, A.D. Cardiac extracellular matrix remodeling: Fibrillar collagens and Secreted Protein Acidic and Rich in Cysteine (SPARC). J. Mol. Cell. Cardiol. 2010, 48, 544-549. [CrossRef]

29. Onorato, M.A.; Fiore, E.; Bayo, J.; Casali, C.; Fernandez-Tomé, M.; Rodríguez, M.; Domínguez, L.; Argemi, J.; Hidalgo, F.; Favre, C.; et al. SPARC inhibition accelerates NAFLD-associated hepatocellular carcinoma development by dysregulating hepatic lipid metabolism. Liver Int. 2021, 41, 1677-1693. [CrossRef]

30. Rempel, S.A.; Hawley, R.C.; Gutiérrez, J.A.; Mouzon, E.; Bobbitt, K.R.; Lemke, N.; Schultz, C.R.; Schultz, L.R.; Golembieski, W.; Koblinski, J.; et al. Splenic and immune alterations of the Sparc-null mouse accompany a lack of immune response. Genes Immun. 2007, 8, 262-274. [CrossRef]

31. Rivera, L.B.; Bradshaw, A.D.; Brekken, R.A. The regulatory function of SPARC in vascular biology. Cell Mol. Life Sci. 2011, 68, 3165-3173. [CrossRef] [PubMed]

32. Mendis, D.B.; Ivy, G.O.; Brown, I.R. SPARC/osteonectin mRNA is induced in blood vessels following injury to the adult rat cerebral cortex. Neurochem. Res. 1998, 23, 1117-1123. [CrossRef] [PubMed]

33. Lee, S.H.; Lee, J.A.; Park, H.S.; Song, Y.S.; Jang, Y.J.; Kim, J.H.; Lee, Y.J.; Heo, Y. Associations among SPARC mRNA expression in adipose tissue, serum SPARC concentration and metabolic parameters in Korean women. Obesity (Silver Spring) 2013, 21, 2296-2302. [CrossRef] [PubMed]

34. Lee, Y.J.; Heo, Y.S.; Park, H.S.; Lee, S.H.; Lee, S.K.; Jang, Y.J. Serum SPARC and matrix metalloproteinase-2 and metalloproteinase-9 concentrations after bariatric surgery in obese adults. Obes. Surg. 2014, 24, 604-610. [CrossRef] [PubMed]

35. Kos, K.; Wong, S.; Tan, B.; Gummesson, A.; Jernas, M.; Franck, N.; Kerrigan, D.; Nystrom, F.H.; Carlsson, L.M.; Randeva, H.S.; et al. Regulation of the fibrosis and angiogenesis promoter SPARC/osteonectin in human adipose tissue by weight change, leptin, insulin, and glucose. Diabetes 2009, 58, 1780-1788. [CrossRef]

36. Shi, D.; Jiang, K.; Fu, Y.; Fang, R.; Liu, X.I.; Chen, J. Overexpression of SPARC correlates with poor prognosis in patients with cervical carcinoma and regulates cancer cell epithelial-mesenchymal transition. Oncol. Lett. 2016, 11, 3251-3258. [CrossRef]

37. Zhong, M.E.; Chen, Y.; Xiao, Y.; Xu, L.; Zhang, G.; Lu, J.; Qiu, H.; Ge, W.; Wu, B. Serum extracellular vesicles contain SPARC and LRG1 as biomarkers of colon cancer and differ by tumour primary location. EBioMedicine 2019, 50, 211-223. [CrossRef]

38. Liu, Y.; Feng, Y.; Wang, X.; Yang, X.; Hu, Y.; Li, Y.; Zhang, Q.; Huang, Y.; Shi, K.; Ran, C.; et al. SPARC Negatively Correlates With Prognosis After Transarterial Chemoembolization and Facilitates Proliferation and Metastasis of Hepatocellular Carcinoma via ERK/MMP Signaling Pathways. Front. Oncol. 2020, 10, 813. [CrossRef]

39. Bloomston, M.; Ellison, E.C.; Muscarella, P.; Al-Saif, O.; Martin, E.W.; Melvin, W.S.; Frankel, W.L. Stromal osteonectin overexpression is associated with poor outcome in patients with ampullary cancer. Ann. Surg. Oncol. 2007, 14, 211-217. [CrossRef]

40. Ikuta, Y.; Nakatsura, T.; Kageshita, T.; Fukushima, S.; Ito, S.; Wakamatsu, K.; Baba, H.; Nishimura, Y. Highly sensitive detection of melanoma at an early stage based on the increased serum secreted protein acidic and rich in cysteine and glypican-3 levels. Clin. Cancer Res. 2005, 11, 8079-8088. [CrossRef]

41. Papapanagiotou, A.; Sgourakis, G.; Karkoulias, K.; Raptis, D.; Parkin, E.; Brotzakis, P.; Panchal, S.; Papavassiliou, A.G. Osteonectin as a screening marker for pancreatic cancer: A prospective study. J. Int. Med. Res. 2018, 46, 2769-2779. [CrossRef] [PubMed]

42. Wang, Z.; Song, H.Y.; An, M.M.; Zhu, L.L. Association of serum SPARC level with severity of coronary artery lesion in type 2 diabetic patients with coronary heart disease. Int. J. Clin. Exp. Med. 2015, 8, 19290-19296. [PubMed]

43. Wu, D.; Li, L.; Yang, M.; Liu, H.; Yang, G. Elevated plasma levels of SPARC in patients with newly diagnosed type 2 diabetes mellitus. Eur. J. Endocrinol. 2011, 165, 597-601. [CrossRef]

44. Pichler, R.H.; Bassuk, J.A.; Hugo, C.; Reed, M.J.; Eng, E.; Gordon, K.L.; Pippin, J.; Alpers, C.E.; Couser, W.G.; Sage, E.H.; et al. SPARC is expressed by mesangial cells in experimental mesangial proliferative nephritis and inhibits platelet-derived-growthfactor-medicated mesangial cell proliferation in vitro. Am. J. Pathol. 1996, 148, 1153-1167.

45. Riedl, I.; Yoshioka, M.; Nishida, Y.; Tobina, T.; Paradis, R.; Shono, N.; Tanaka, H.; St-Amand, J. Regulation of skeletal muscle transcriptome in elderly men after 6 weeks of endurance training at lactate threshold intensity. Exp. Gerontol. 2010, 45, 896-903. [CrossRef] [PubMed]

46. Petersson, S.J.; Jørgensen, L.H.; Andersen, D.C.; Nørgaard, R.C.; Jensen, C.H.; Schrøder, H.D. SPARC is up-regulated during skeletal muscle regeneration and inhibits myoblast differentiation. Histol. Histopathol. 2013, 28, 1451-1460. [PubMed] 
47. Brekken, R.A.; Sage, E.H. SPARC, a matricellular protein: At the crossroads of cell-matrix communication. Matrix Biol. 2001, 19, 816-827. [CrossRef]

48. Hua, H.W.; Jiang, H.S.; Jia, L.; Jia, Y.P.; Yao, Y.L.; Chen, Y.W.; Jiang, F.; Lu, D.Q.; Zhou, Q.; Jiang, M.W.; et al. SPARC regulates ferroptosis induced by sorafenib in human hepatocellular carcinoma. Cancer Biomark. 2021, 1-9. [CrossRef] 